\title{
Kinerja Perusahaan Pembiayaan Syariah Di Indonesia Sebelum Dan Sesudah Diberlakukannya Surat Edaran OJK No.48 Tahun 2016 Tentang Besaran Uang Muka Pembiayaan Kendaraan Bermotor Syariah
}

\author{
Nur Wachidah Yulianti \\ UIN Syarif Hidayatullah Jakarta \\ wachi@uinjkt.ac.id
}

\begin{abstract}
Abstrak Penelitian ini bertujuan untuk mengetahui kinerja perusahaan pembiayaan syariah di Indonesia satu tahun sebelum yaitu tahun 2016 dan dua tahun setelah yaitu tahun 2017 dan 2018 diberlakukannya Surat Edaran Otoritas Jasa Keuangan No 48 Tahun 2016 tentang besaran Uang Muka Pembiayaan Kendaraan Bermotor Syariah. Metode yang digunakan dalam penelitian ini adalah Wilcoxon match pair test. Dengan menggunakan alpha 5\%, hasil penelitian menunjukkan nilai signifikansi rasio FAR, GR, dan MSMD berada di bawah alpha. Hal ini berarti terdapat perbedaan rasio FR, GR dan MSMD sebelum dan setelah adanya regulasi tersebut.
\end{abstract}

Kata Kunci Wilcoxon match pair test, financing asset ratio, gearing ratio, rasio modal sendiri modal disetor

\section{PENDAHULUAN}

Salah satu Industri keuangan Non-bank (IKNB) syariah yang diawasi oleh Otoritas Jasa Keuangan (OJK) adalah lembaga pembiayaan syariah. Lembaga pembiayaan syariah mencakup perusahaan pembiayaan syariah, perusahaan modal ventura syariah dan perusahaan pembiayaan infrastruktur. Berdasarkan data OJK diketahui bahwa dalam kurun waktu 2012 sampai dengan 2016, sektor lembaga pembiayaan syariah mengalami perkembangan yang positif baik dari perkembangan aset maupun jumlah pelaku usaha (Otoritas Jasa Keuangan, 2017). Perkembangan aset lembaga pembiayaan syariah dari tahun 2012 hingga tahun 2016 sebagaimana yang terlihat dalam tabel 1.

Tabel 1. Perkembangan aset Lembaga Pembiayaan Syariah

\begin{tabular}{lccccc}
\hline & $\mathbf{2 0 1 2}$ & $\mathbf{2 0 1 3}$ & $\mathbf{2 0 1 4}$ & $\mathbf{2 0 1 5}$ & $\mathbf{2 0 1 6}$ \\
\hline Lembaga Pembiayaan Syariah & $22.889,63$ & $24.950,34$ & $24.152,19$ & $22.831,12$ & 36.938 \\
\hline
\end{tabular}

Sumber: Roadmap Pengembangan Keuangan Syariah Indonesia 2017-2019, Otoritas Jasa Keuangan (dalam milyar rupiah)

Tabel 1 menunjukkan bahwa perkembangan aset Lembaga Pembiayaan Syariah mengalami trend yang positif dari tahun 2012 hingga 2016. Perkembangan aset yang sangat signifikan terjadi pada tahun 2016. 
Selain dari sisi perkembangan aset, Lembaga Pembiayaan Syariah juga menunjukkan perkembangan yang positif dari sisi pelaku usaha yaitu perusahaan yang secara penuh melakukan kegiatan usaha syariah (full fledged) dan perusahaan konvensional yang melakukan sebagian kegiatan usaha syariah (unit syariah) sebagaimana terlihat dalam tabel 2.

Tabel 2. Perkembangan jumlah pelaku usaha Lembaga Pembiayaan Syariah

\begin{tabular}{|c|c|c|c|c|c|c|c|c|c|c|}
\hline & \multicolumn{2}{|c|}{2012} & \multicolumn{2}{|c|}{2013} & \multicolumn{2}{|c|}{2014} & \multicolumn{2}{|c|}{2015} & \multicolumn{2}{|c|}{2016} \\
\hline & FF & $\mathbf{U S}$ & FF & US & FF & US & FF & US & FF & US \\
\hline Lembaga Pembiayaan Syariah & 6 & 32 & 6 & 42 & 7 & 41 & 7 & 39 & 7 & 42 \\
\hline a. Perusahaan Pembiayaan & 2 & 32 & 2 & 42 & 3 & 41 & 3 & 37 & 3 & 38 \\
\hline b. Perusahaan modal ventura & 4 & 0 & 4 & 0 & 4 & 0 & 4 & 2 & 4 & 3 \\
\hline c. Lembaga pembiayaan infrastruktur & 0 & 0 & 0 & 0 & 0 & 0 & 0 & 0 & 0 & 1 \\
\hline
\end{tabular}

*FF= Full Fledged $* \mathrm{US}=$ Unit Syariah

Sumber: Roadmap Pengembangan Keuangan Syariah Indonesia 2017-2019, Otoritas Jasa Keuangan

Walaupun menunjukkan perkembangan yang positif baik dari perkembangan asset maupun jumlah pelaku usaha, namun pertumbuhan Lembaga Pembiayaan Syariah belum dapat mengimbangi pertumbuhan Lembaga Pembiayaan konvensional. Hal ini dapat dilihat dari pangsa pasar (market share) lembaga pembiayaan syariah yang hanya sebesar 7,24\% dari total pembiayaan. Angka ini menunjukkan bahwa Lembaga Pembiayaan Syariah di Indonesia masih perlu terus dikembangkan.

Guna mengembangkan Industri Keuangan Non Bank (IKNB) Syariah di Indonesia termasuk di dalamnya Lembaga Pembiayaan Syariah, Otoritas Jasa Keuangan mengusung Roadmap Pengembangan Keuangan Syariah Indonesia 2017-2019 yang mempunyai visi untuk mewujudkan industri jasa keuangan syariah yang tumbuh dan berkelanjutan, berkeadilan, serta memberikan kontribusi bagi perekonomian nasional dan stabilitas sistem keuangan menuju terwujudnya Indonesia sebagai pusat keuangan syariah dunia (Otoritas Jasa Keuangan, 2017).

Visi untuk mewujudkan industri jasa keuangan syariah khususnya Lembaga Pembiayaan Syariah yang tumbuh dan berkelanjutan serta berkeadilan nampaknya sulit direalisasikan. Pasalnya, setelah diterbitkannya Surat Edaran OJK (SEOJK) No. 47 tahun 2016 tentang Besaran Uang Muka Pembiayaan Kendaraan Bermotor dan SEOJK No.48 tahun 2016 tentang Besaran Uang Muka Pembiayaan Kendaraan Bemotor Syariah tanggal 13 Desember 2016, lembaga pembiayaan syariah khususnya perusahaan pembiayaan syariah tidak lagi dapat memberikan Down Payment (DP) yang rendah dan menjadi "primadona" konsumen pembiayaan kendaraan bermotor (Kontan.co.id, 2018).

Hal ini dikarenakan, melalui kedua surat edaran itu OJK menetapkan bahwa batas besaran DP didasarkan pada rasio kredit bermasalah atau Non-Performing Financing (NPF) dan aset produktif bermasalah dari masing- masing perusahaan atau Unit Usaha Syariah (UUS). Dengan ketentuan tersebut, maka perusahaan pembiayaan baik konvensional maupun syariah dengan rasio NPF dan aset produktif bermasalah sebesar 1\% dapat menetapkan besaran DP minimum 5\% kepada nasabahnya untuk pembiayaan kendaraan bermotor. Besaran tersebut tentunya membuat 
perusahaan pembiayaan konvensional bisa kembali bersaing dengan perusahaan pembiayaan syariah (Kontan.co.id, 2018).

Menurut Ketua Umum Asosiasi Perusahaan Pembiayaan Indonesia (APPI) Suwandi Wiratno pembiayaan syariah akan tumbuh kalau ada insentif yang spesial yaitu DP yang berbeda dengan perusahaan pembiayaan konvensional. Menurutnya sebelum ada regulasi SE OJK No.48 tahun 2016 tentang Besaran Uang Muka Pembiayaan Kendaraan Bemotor Syariah, perusahaan pembiayaan syariah tumbuh dengan cepat (Bisnis.com, 2018).

Berdasarkan paparan di atas, penelitian ini bermaksud untuk menguji kinerja perusahaan pembiayaan syariah di Indonesia yang terdiri dari Financing to Asset Ratio, Gearing Ratio dan Rasio Modal sendiri-modal disetor sebelum dan sesudah diberlakukannya SE OJK No.48 tahun 2016 tentang Besaran Uang Muka Pembiayaan Kendaraan Bemotor Syariah.

\section{LANDASAN TEORI}

\section{Lembaga Pembiayaan Syariah dan Perusahaan Pembiayaan Syariah}

Menurut Peraturan Pemerintah (PP) No.9 Tahun 2009 tentang Lembaga Pembiayaan, yang dimaksud Lembaga pembiayaan adalah badan usaha yang melakukan kegiatan pembiayaan dalam bentuk penyediaan dana atau barang modal dan dilarang menarik dana dari masyarakat seperti apa yang dilakukan oleh Bank yang berupa Tabungan, Giro maupun deposito (Republik Indonesia, 2009). Berdasarkan terminologi tersebut maka yang dimaksud dengan lembaga pembiayaan syariah adalah badan usaha yang melakukan kegiatan pembiayaan dalam bentuk penyediaan dana atau barang modal berdasarkan akad dan prinsip syariah, serta dilarang menarik dana dari masyarakat seperti apa yang dilakukan oleh Bank yang berupa Tabungan, Giro maupun Deposito. Lembaga pembiayaan berdasarkan PP No.9 Tahun 2009 di atas meliputi Perusahaan pembiayaan, Perusahaan modal ventura dan Perusahaan pembiayaan infrastruktur.

Perusahaan Pembiayaan Syariah adalah badan usaha yang khusus didirikan untuk melakukan Sewa Guna Usaha, Anjak Piutang, Pembiayaan Konsumen, dan/atau usaha Kartu Kredit berdasarkan prinsip syariah. Berdasarkan definisi tersebut, maka produk perusahaan pembiayaan syariah berupa pembiayaan atas sewa guna usaha, anjak piutang, pembiayaan konsumen dan atau usaha kartu kredit berdasarkan akad dan prinsip syariah.

Berdasarkan Peraturan OJK No.31/P.OJK/2014 (Otoritas Jasa Keuangan, 2014) dinyatakan bahwa dalam hal perusahaan pembiayaan syariah melakukan pembiayaan jual beli untuk kendaraan bermotor, perjanjian pembiayaan syariah wajib mencantumkan nilai uang muka (down payment/urbun). Berdasarkan SE OJK No 48 Tahun 2016 (Otoritas Jasa Keuangan, 2016), Uang Muka (Down Payment/Urbun) Pembiayaan Kendaraan Bermotor adalah pembayaran di muka atau uang muka secara tunai yang sumber dananya berasal dari konsumen (selffinancing) dalam rangka Pembiayaan Jual Beli untuk kendaraan bermotor. Batasan Down Payment didasarkan pada tingkat 
kredit bermasalah atau non-performing financing (NPF) setiap perusahaan pembiayaan atau rasio aset bermasalah pada perusahaan atau unit usaha syariah (UUS) multifinance. Dengan adanya ketentuan tersebut, maka perusahaan pembiayaan dengan rasio NPF sekitar $1 \%$ yang menyalurkan pembiayaan bersifat konvensional dapat menerapkan besaran DP minimum 5\%. Besaran minimum DP sebesar 5\% juga dapat diberlakukan bagi perusahaan pembiayaan syariah atau UUS yang mempunyai nilai rasio aset produktif bermasalah lebih rendah atau sama dengan $1 \%$.

\section{Kinerja Perusahaan Pembiayaan Syariah}

Kinerja merupakan hasil pekerjaan yang mempunyai hubungan kuat dengan tujuan strategis organisasi, kepuasan konsumen, dan memberikan kontribusi pada ekonomi. Menurut Hongren dan Datar (2008), pengukuran kinerja secara garis besar berdasarkan kriteria dan informasi yang dihasilkan dapat dibagi menjadi dua, yaitu kinerja keuangan dan non keuangan (Nasuha, 2012).

Kinerja keuangan perusahaan pembiayaan syariah dapat dilihat dari beberapa rasio antara lain, Financing to Assets Ratio (FAR) atau rasio atau perbandingan antara piutang pembiayaan terhadap total asset. Rasio ini menggambarkan sejauh mana perusahaan pembiayaan dapat menyalurkan pembiayaan dari total aset yang mereka miliki. Semakin besar FAR maka maka semakin banyak pembiayaan yang disalurkan kepada konsumen dari total aset yang dimiliki perusahaan pembiayaan syariah.

Gearing Ratio (GR) atau rasio total pinjaman terhadap modal sendiri dan pinjaman subordinasi setelah dikurangi penyertaan modal yang ada. Pinjaman subordinasi yang masuk ke dalam perhitungan gearing ratio sebanyak-banyak sebesar 50\% dari modal disetor. Menurut Pasal 40 Peraturan OJK No 31 Tahun 2014 (Otoritas Jasa Keuangan, 2014) Perusahaan Pembiayaan Syariah wajib memenuhi ketentuan gearing ratio paling tinggi 10 (sepuluh) kali. Sebagai ilustrasi kecil dari ketentuan tersebut, perusahaan bermodal Rp100 miliar dapat memperoleh pinjaman atau utang sebagai sumber pendanaan untuk menyalurkan pembiayaannya maksimal sebesar 10 kali dari modal yaitu Rp1 triliun.

Rasio Modal Sendiri-Modal Disetor atau rasio perbandingan antara modal sendiri terhadap modal disetor. Menurut Pasal 32 Peraturan OJK No 31 Tahun 2014 (Otoritas Jasa Keuangan, 2014) dinyatakan bahwa Perusahaan Pembiayaan Syariah wajib memiliki rasio Ekuitas (modal sendiri) terhadap Modal Disetor paling rendah sebesar 50\% (lima puluh persen).

\section{METODOLOGI PENELITIAN}

Data yang digunakan dalam penelitian ini seluruhnya menggunakan data sekunder yang diperoleh dari Statistik Bulanan IKNB Syariah mulai bulan Januari 2015 sampai dengan Desember 2018 yang diunduh dari website www.ojk.go.id. Penelitian ini bertujuan untuk melihat kinerja perusahaan pembiayaan syariah sebelum dan setelah diberlakukannya SE OJK No 48 tahun 2016. Oleh karena SE OJK No 48 tahun 2016 diundangkan tanggal 13 Desember 2016, maka periode yang digunakan untuk melihat kinerja sebelum penerapan regulasi tersebut adalah 12 bulan 
terhitung dari bulan Januari 2016 sampai Desember 2016 dan periode yang digunakan untuk melihat kinerja setelah penerapan regulasi tersebut 24 bulan terhitung dari bulan Januari 2017 sampai Desember 2018.

Hipotesis yang diajukan dalam penelitian ini adalah H1o = Financing to Asset Ratio (FAR) perusahaan pembiayaan syariah sebelum SE OJK No.48/2016 sama dengan setelah SE OJK No.48/2016

$\mathrm{H} 1 \mathrm{a}=$ Financing to Asset Ratio (FAR) perusahaan pembiayaan syariah sebelum SE OJK No.48/2016 tidak sama dengan setelah SE OJK No.48/2016

H2o = Gearing Ratio (GR) perusahaan pembiayaan syariah sebelum SE OJK No.48/2016 sama dengan setelah SE OJK No.48/2016

$\mathrm{H} 2 \mathrm{a}=$ Gearing Ratio (GR) perusahaan pembiayaan syariah sebelum SE OJK No.48/2016 tidak sama dengan setelah SE OJK No.48/2016

H3o = Rasio Modal Sendiri-Modal Disetor perusahaan pembiayaan syariah sebelum SE OJK No.48/2016 sama dengan setelah SE OJK No.48/2016

$\mathrm{H} 3 \mathrm{a}=$ Rasio Modal Sendiri-Modal Disetor perusahaan pembiayaan syariah sebelum SE OJK No.48/2016 tidak sama dengan setelah SE OJK No.48/2016

Analisis statistik inferensial yang digunakan untuk menjawab hipotesis penelitian adalah dengan teknik uji paired sample t test atau Wilcoxon match pair test. Baik Paired sample t test maupun Wilcoxon match pair test merupakan uji yang digunakan untuk mengetahui apakah terdapat perbedaan rata-rata dua kelompok yang berpasangan atau berhubungan. Perbedaannya terletak pada distirbusi normal dari data. Jika data tidak terdistribusi normal maka akan dilakukan uji Wilcoxon Match Pair Test. Namun, jika data terdistribusi normal maka paired samples t test digunakan. Formula Paired sample t test yang digunakan adalah sebagai berikut (Lind, Marchal, \& Wathen, 2008).

$t=\frac{\bar{d}}{s_{d} / \sqrt{n}}$

Dimana,

$\bar{d}=$ perbedaan rata-rata di antara di kedua kelompok

$s_{d}=$ standar deviasi dari perbedaan di antara kedua kelompok

$\mathrm{n}=$ jumlah dari observasi yang berpasangan

Dengan tingkat kepercayaan 95\% atau $\alpha=0,05$ (5\%), maka keputusan untuk menolak atau tidak menolak hipotesis tersebut sebagai berikut.

Ho ditolak jika $p$ value $<0,05$

Ho tidak ditolak jika $p$ value $>0,05$ 
Adapun uji normalitas yang digunakan adalah One Samples Kolmogorov Smirnov Test, dengan hipotesis sebagai berikut.

Ho: terdistribusi normal

Ha: tidak terdistribusi normal

Dengan tingkat kepercayaan 95\% atau $\alpha=0,05$ (5\%), maka keputusan untuk menolak atau tidak menolak hipotesis tersebut sebagai berikut.

Ho ditolak jika $p$ value (Asymp Sig 2 tailed) $<0,05$

Ho tidak ditolak jika $p$ value (Asymp Sig 2 tailed) $>0,05$

\section{HASIL DAN PEMBAHASAN}

Berikut ini adalah statistik deskriptif atau gambaran kinerja perusahaan pembiayaan syariah di Indonesia yang meliputi Financing to Aset Ratio (FAR), Gearing Ratio (GR) dan rasio Modal Sendiri terhadap Modal Disetor (MSMD). Data terkait rasio-rasio tersebut diperoleh dari Statistik Bulanan IKBN yang diterbitkan OJK dari tahun 2016 sampai dengan 2018.

\section{Financing to Aset Ratio}



sumber: Statistik Bulanan IKNB Syariah, OJK, data diolah

Berdasarkan grafik di atas dapat dilihat, pada tahun 2016 perusahaan pembiayaan syariah mampu menyalurkan pembiayaan rata-rata sebesar 92\%. Namun pada tahun 2017 dan 2018 kemampuan perusahaan pembiayaan syariah menyalurkan pembiayaan mengalami penurunan yaitu rata-rata sebesar 90,3\% dan 87,6\%. Sebagaimana diketahui bahwa pada tahun 2017 dan 2018 adalah tahun pertama pemberlakuan SE OJK No.48/2016 tentang Besaran Uang Muka Pembiayaan Kendaraan 
Bemotor Syariah. Dengan demikian kemampuan perusahaan pembiayaan syariah dalam menyalurkan pembiayaan mengalami penurunan seiring dengan dikeluarkannya regulasi tersebut.

\section{Gearing Ratio}

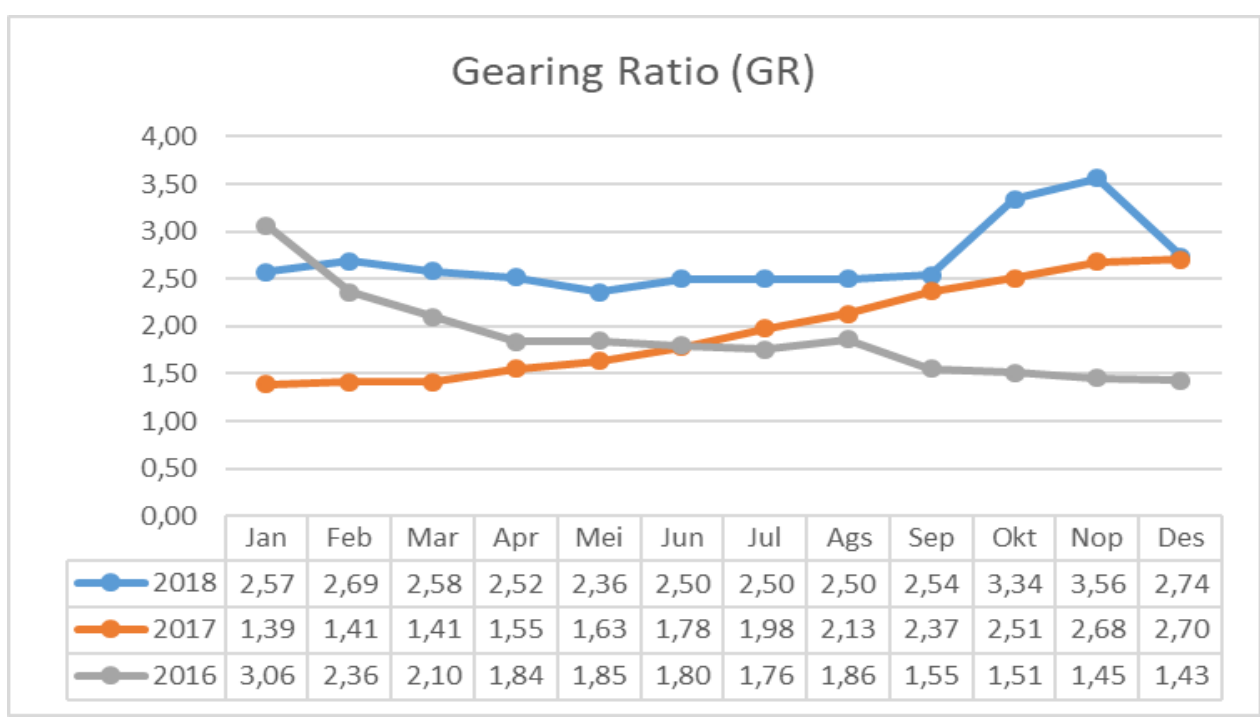

sumber: Statistik Bulanan IKNB Syariah, OJK, data diolah

Berdasarkan grafik di atas dapat dilihat, pada tahun 2016 gearing ratio perusahaan pembiayaan syariah rata-rata sebesar 1,88 kali. Artinya, dari ekuitas yang dimiliki oleh perusahaan pembiayaan syariah, perusahaan pembiayaan syariah hanya mampu mendapatkan pinjaman atau utang sebagai sumber pendanaan untuk menyalurkan pembiayaannya sebesar 1,88 kali. Namun pada tahun 2017 dan 2018 kemampuan perusahaan pembiayaan syariah mendapatkan pinjaman atau utang sebagai sumber pendanaan untuk menyalurkan pembiayaannya berdasarkan ekuitas yang dimiliki mengalami peningkatan yaitu rata-rata sebesar 1,96 kali dan 2,70 kali. 


\section{Rasio Modal Sendiri terhadap Modal disetor}

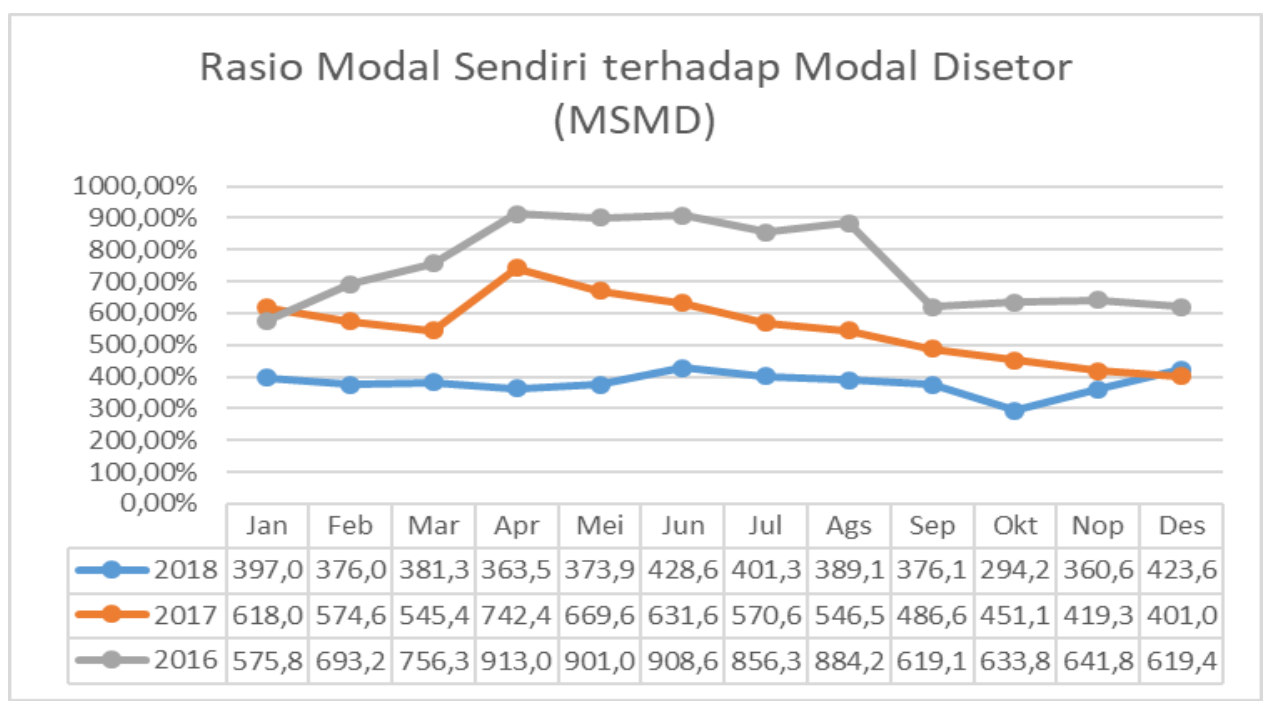

sumber: Statistik Bulanan IKNB Syariah, OJK, data diolah

Berdasarkan grafik di atas dapat dilihat, pada tahun 2016 rasio modal sendiri (ekuitas) terhadap modal disetor perusahaan pembiayaan syariah rata-rata sebesar 750,25\%. Namun pada tahun 2017 dan 2018 rasio modal sendiri (ekuitas) terhadap modal disetor mengalami penurunan yaitu ratarata sebesar $554,77 \%$ dan $380,48 \%$.

\section{Analisis Data}

Analisis statistik inferensial yang digunakan untuk menjawab hipotesis penelitian adalah dengan teknik uji paired sample $t$ test atau Wilcoxon match pair test. Penggunaan motode statistic inferensial ini tergantung pada hasil normalitas data dari setiap variabel penelitian. Jika data setiap variabel penelitian terdistribusi normal maka paired sample t test akan digunakan, namun jika tidak maka akan digunakan Wilcoxon match pair test. Uji Kolmogorov smirnov digunakan untuk melihat normalitas data setiap variabel dalam penelitian ini. Adapun hasil uji normalitas data melalui Kolmogorov smirnov sebagaimana terlihat dalam tabel 3.

Tabel 3. Hasil Uji Normalitas dengan Kolmogorov Smirnov

\begin{tabular}{lccl}
\hline \multicolumn{1}{c}{ Variabel } & $\begin{array}{c}\text { Nilai Asymp.Sig } 2 \text { tailed } \\
(\boldsymbol{p} \text {-value })\end{array}$ & $\begin{array}{c}\text { Alpha } \\
(\boldsymbol{\alpha})\end{array}$ & \multicolumn{1}{c}{ Keterangan } \\
\hline FAR sebelum & 0,200 & 0,05 & Terdistribusi Normal \\
\hline FAR setelah & 0,079 & 0,05 & Terdistribusi Normal \\
\hline GR sebelum & 0,017 & 0,05 & Tidak terdistribusi Normal \\
\hline GR setelah & 0,015 & 0,05 & Tidak terdistribusi Normal \\
\hline MSMD sebelum & 0,158 & 0,05 & Terdistribusi Normal \\
\hline
\end{tabular}


MSMD setelah 0,005 0,05

Tidak terdistribusi Normal

Sumber: Data diolah

Berdasarkan tabel 3 dapat disimpulkan bahwa terdapat 3 variabel penelitian yang terdistribusi normal dan terdapat 3 variabel penelitian yang tidak terdistribusi normal. Oleh karena hasil yang tidak sama, maka penelitian ini memutuskan untuk menggunakan uji Wilcoxon match pair test pada semua variabel.

Tabel 4. Hasil Uji Wilcoxon Match Pair Test

\begin{tabular}{ccccccc}
\hline Hipotesis & Variabel & $\mathbf{Z}$ & Sig & $\boldsymbol{\alpha}$ & Keputusan & Keterangan \\
\hline H1a & FAR & -3.059 & 0.002 & 0.05 & Tidak ditolak & Berbeda \\
\hline H2a & GR & -2.824 & 0.005 & 0.05 & Tidak ditolak & Berbeda \\
\hline H3a & MSMD & -3.059 & 0.002 & 0.05 & Tidak ditolak & Berbeda \\
\hline
\end{tabular}

Sumber: Data diolah

Tabel 4 merupakan jawaban dari setiap hipotesis yang diajukan dalam penelitian ini. Dengan membandingkan kinerja keuangan perusahaan pembiayaan syariah yang terdiri dari FAR, GR dan MSMD satu tahun sebelum dan dua tahun setelah diberlakukannya SE OJK No 48 Tahun 2016 tentang Besaran Uang Muka Pembiayaan Kendaraan Bemotor Syariah, diperoleh hasil uji Wilcoxon match pair test untuk semua variabel yaitu FAR, GR dan MSMD memiliki nilai signifikansi di bawah alpha 0.05, masing masing sebesar 0.002, 0.005 dan 0.002. Hasil ini menunjukkan bahwa ada perbedaan kinerja keuangan perusahaan pembiayaan syariah di Indonesia sebelum dan setelah diberlakukannya regulasi tersebut. Dengan demikian H1a, H2a dan H3a tidak ditolak.

Tabel 5. Hasil perbandingan kinerja

\begin{tabular}{|c|c|c|c|c|c|c|c|}
\hline \multirow[b]{2}{*}{ Kinerja } & \multicolumn{3}{|c|}{ Negatif } & \multicolumn{3}{|c|}{ Positif } & \multirow[b]{2}{*}{ Ties } \\
\hline & $\mathrm{N}$ & $\begin{array}{l}\text { Mean } \\
\text { Ranks }\end{array}$ & $\begin{array}{c}\text { Sum of } \\
\text { Ranks }\end{array}$ & $\mathrm{N}$ & $\begin{array}{l}\text { Mean } \\
\text { Ranks }\end{array}$ & $\begin{array}{l}\text { Sum of } \\
\text { Ranks }\end{array}$ & \\
\hline FAR sebelum - FAR setelah & 12 & 6.5 & 78 & 0 & 0 & 0 & 0 \\
\hline GR sebelum - GR setelah & 1 & 3 & 3 & 11 & 6.82 & 75 & 0 \\
\hline MSMD sebelum - MSMD setelah & 12 & 6.5 & 78 & 0 & 0 & 0 & 0 \\
\hline
\end{tabular}

Sumber: Data diolah

Berdasarkan output dalam tabel 4 maka diperoleh hasil perbandingan kinerja sebagaimana terlihat dalam tabel 5. Berdasarkan tabel 5, diketahui kinerja FAR sebelum-FAR ${ }_{\text {setelah }}$ dan MSMD $_{\text {sebelum }}-$

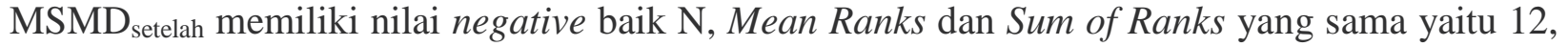
6.5 dan 78. Hal ini menunjukkan bahwa pada keduanya terdapat penurunan sebanyak 12 dengan rata-rata penurunan sebesar 6.5 dan penurunan jumlah ranking sebanyak 78 . Namun pada nilai positive baik N, Mean Ranks dan Sum of Ranks keduanya memiliki nilai yang sama yaitu masing- 
masing 0. Hal ini menunjukkan bahwa pada keduanya tidak ada peningkatan. Nilai Ties untuk keduanya pun sama yaitu 0 , hal ini menunjukkan bahwa perbedaan dalam kinerja FAR dan MSMD baik sebelum dan setelah pemberlakuan regulasi bernilai 0 .

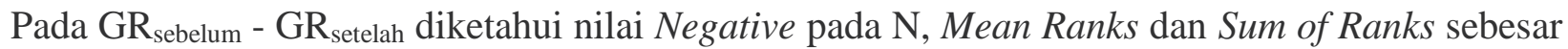
1, 3 dan 3. Hasil ini menunjukkan bahwa ada penurunan pada rasio GR sebanyak 1 dengan penurunan nilai rata-rata ranking sebesar 3 dan penurunan jumlah ranking juga sebesar 3 . Namun pada nilai positive diketahui $\mathrm{N}$, mean ranks dan sum of ranks sebesar 11, 6,82 dan 75. Hasil ini menunjukkan bahwa pada rasio GR terdapat 11 peningkatan yang terjadi dari sebelum ke setelah pemberlakuan regulasi tersebut, dengan rata-rata peningkatan tersebut sebesar 6,82 dan peningkatan jumlah ranking sebesar 75 .

\section{PENUTUP}

Berdasarkan hasil pengujian Wilcoxon match pair test didapatkan bahwa kinerja atau rasio FR, GR dan MSMD berbeda antara satu tahun sebelum dan dua tahun setelah diberlakukannya Surat Edaran (SE) OJK No 48 Tahun 2016 tentang Besaran Uang Muka Pembiayaan Kendaraan Bemotor Syariah. Hasil ini diketahui dengan melihat nilai signifikansi ketiganya yang berada di bawah alpha $(\alpha) 5 \%$ atau 0,05 . Hasil pengujian ini juga didapatkan bahwa rasio FR dan MSMD mengalami penurunan semenjak diberlakukannya regulasi tersebut. Namun tidak bagi rasio GR, setelah diberlakukannya regulasi tersebut rasio GR justru mengalami peningkatan.

Dengan menurunnya rasio FAR mengindikasikan bahwa penyaluran pembiayaan oleh perusahaan pembiayaan syariah mengalami penurunan. Hal ini bisa jadi disebabkan oleh pemberian DP yang tidak lagi ringan di mata para konsumen, sehingga konsumen lebih memilih melakukan pembiayaan pada perusahaan pembiayaan konvensional. Tentunya hal ini dapat membuat pertumbuhan perusahaan pembiayaan syariah menjadi stagnan atau bahkan "mati". Dengan demikian, jika dalam Roadmap Pengembangan Keuangan Syariah Indonesia 2017-2019 yang mempunyai visi untuk mewujudkan industri jasa keuangan syariah yang tumbuh dan berkelanjutan, sudah semestinya regulasi tersebut perlu direviu kembali.

\section{DAFTAR PUSTAKA}

Bisnis.com. (2018, Maret 14). Pembiayaan Syariah Butuh Insentif. Retrieved from https://ifsa.or.id/id/frame/news/2678: https://ifsa.or.id/id/frame/news/2678

Kontan.co.id. (2018, November 25). Ini penyebab kinerja industri pembiayaan syariah di tanah air lesu. Retrieved from Kontan.co.id: https://keuangan.kontan.co.id/news/ini-penyebabkinerja-industri-pembiayaan-syariah-di-tanah-air-lesu

Lind, Marchal, \& Wathen. (2008). Statistical Techniques in Business and Economics With Global Data Sets 13th Edition. New York: McGraw-Hill/Irwin. 
Nasuha, A. (2012). DAMPAK KEBIJAKAN SPIN-OFF TERHADAP KINERJA BANK SYARIAH. Al-Iqtishad: Vol. IV, No. 2, Juli 2012 , 241-258.

Otoritas Jasa Keuangan. (2014). Peraturan OJK No 31 Tahun 2014 Tentang Penyelenggaraan Usaha Pembiayaan Syariah. Jakarta: Otoritas Jasa Keuangan.

Otoritas Jasa Keuangan. (2017). Roadmap Pengembangan Keuangan Syariah Indonesia $2017-$ Retrieved from Otoritas Jasa Keuangan https://www.ojk.go.id/id/kanal/syariah/berita-dan-kegiatan/publikasi/Pages/RoadmapPengembangan-Keuangan-Syariah-Indonesia-2017-2019.aspx

Otoritas Jasa Keuangan. (2017). ROADMAP PENGEMBANGAN KEUANGAN SYARIAH INDONESIA 2017-2019. Jakarta: Otoritas Jasa Keuangan.

Republik Indonesia. (2009). PERATURAN PRESIDEN REPUBLIK INDONESIA NOMOR 9 TAHUN 2009 TENTANG LEMBAGA PEMBIAYAAN. Deputi Sekretaris Kabinet Bidang Hukum. 